\title{
Tone \\ (Technology Coverage)
}

\section{AUTHOR}

Gwendolin Gurr, Julia Metag

\section{KEYWORDS}

assessment/evaluation of technology, risk and benefit of technology

\section{BRIEF DESCRIPTION}

The variable tone measures the overall impression of the technology covered in a unit of analysis (e.g. newspaper article). The variable addresses the question whether the overall interpretation of a technology within a media item is rather positive, neutral or negative. In the case of technology, the variable tone is in part related to risk and benefits portrayed in the news media coverage (e.g. Nisbet \& Lewenstein 2002).

\section{FIELD OF APPLICATION/THEORETICAL FOUNDATION}

The tone of news media coverage is analyzed in various domains to understand how actors, topics or current issues are evaluated in the media coverage. The tone reflects how journalists interpret issues, such as a technology or technological developments. It is assumed that the tone of the news media coverage is particularly relevant regarding the recipients' interpretation of issues or actors in question.

\section{EXAMPLE STUDIES}

Lemańczyk (2012); Kojo \& Innola (2017)

\section{INFORMATION ON LEMAŃCZYK, 2012}

Authors: Szczepan Lemańczyk

Research question/research interest: Frames, themes and tone used in the Polish coverage of nanotechnology

Object of analysis: the two largest Polish national broadsheets (elite newspapers): Gazeta Wyborcza and Rzeczpospolita

Time frame of analysis: 2004-2009

INFORMATION ON KOJO \& INNOLA, 2017

Authors: Matti Kojo, Eeva Innola

Research question/research interest: How is CCS handled and framed in

the Finnish media and to what extent?

Object of analysis: 10 Finnish newspapers

Timeframe of analysis: 1996-2015

\section{INFORMATION ABOUT VARIABLE}

see Table 1

\section{REFERENCES}

Lemańczyk, Szczepan (2012): Between National Pride and the Scientific Success of "Others": The Case of Polish Press Coverage of Nanotechnology, 20042009. In: Nanoethics 6(2), 101-115.

Kojo, Matti; Innola, Eeva (2017): Carbon Capture and Storage in the Finnish Print Media. In: Risk, Hazards \& Crisis in Public Policy 8(2), 113-146.

\section{FURTHER REFERENCES}

Nisbet, M. C., \& Lewenstein, B. V. (2002). Biotechnology and the American Media: The Policy Process and the Elite Press, 1970 to 1999. Science Communication, 23(4), 359-391. 
Table 1.

\begin{tabular}{|c|c|c|c|c|c|}
\hline Authors & $\begin{array}{l}\text { Variable name/ } \\
\text { definition }\end{array}$ & $\begin{array}{l}\text { Level of } \\
\text { analysis }\end{array}$ & Values & $\begin{array}{l}\text { Scale } \\
\text { Level }\end{array}$ & Reliability \\
\hline $\begin{array}{l}\text { Lemańczyk } \\
\text { (2012) }\end{array}$ & general tone & article & $\begin{array}{ll}\text { - } & \text { Positive } \\
\text { - } & \text { Neutral } \\
\text { - } & \text { Negative }\end{array}$ & nominal & $\mathrm{N} / \mathrm{A}$ \\
\hline $\begin{array}{l}\text { Kojo \& Innola } \\
(2017)\end{array}$ & tone & article & $\begin{array}{ll}\text { - } & \text { Positive } \\
\text { - } & \text { Negative } \\
\text { - } & \text { Neutral } \\
\text { - } & \text { Mixed }\end{array}$ & nominal & $\mathrm{N} / \mathrm{A}$ \\
\hline
\end{tabular}

